\title{
PREKOGRANIČNO POSLOVANJE DRUŠTAVA ZA OSIGURANJE NA JEDINSTVENOM TRŽIŠTU EUROPSKE UNIJE - POGLED IZ HRVATSKE
}

\author{
Izv. prof. dr. sc. Adriana Vincenca Padovan* \\ Mirela Duvnjak, dipl. iur.**
}

\author{
UDK 368::061.1EU \\ 339.923:061.1EU \\ https://doi.org/10.30925/zpfsr.42.3.8 \\ Ur.: 7. srpnja 2021. \\ Pr.: 2. studenoga 2021. \\ Prethodno priopćenje
}

\begin{abstract}
Sažetak
Autorice analiziraju pravni okvir za prekogranično poslovanje društava za osiguranje unutar EU-a s posebnim osvrtom na važeće pravno uređenje u Republici Hrvatskoj te obrađuju statističke podatke o poslovima osiguranja koje društva za osiguranje obavljaju na temelju prava slobode poslovnog nastana, odnosno slobode pružanja usluga osiguranja u Republici Hrvatskoj i iz Republike Hrvatske u drugim državama članicama EU-a. Time se nastoji prikazati stvaran učinak primjene propisa Europske unije o slobodi poslovnog nastana i slobodi pružanja usluga osiguranja na domaću industriju osiguranja te ukazati na izazove koji se takvom liberalizacijom u sektoru osiguranja postavljaju pred osiguratelje i druge pružatelje usluga osiguranja u Republici Hrvatskoj.
\end{abstract}

Ključne riječi: sloboda pružanja usluga; sloboda poslovnog nastana; Europska unija; osiguranje; reosiguranje; Direktiva 2009/138/ EZ; Direktiva (EU) 2016/97; Zakon o osiguranju.

\section{UVOD}

Sloboda pružanja usluga i sloboda poslovnog nastana na jedinstvenom tržištu Europske unije (dalje: EU) zajamčene su osnivačkim ugovorima EU-a. Ugovor o funkcioniranju Europske Unije ${ }^{1}$ (dalje: UFEU) u čl. 26.2. propisuje da unutarnje tržište EU-a obuhvaća područje bez unutarnjih granica na kojem se osigurava slobodno kretanje robe, osoba, usluga i kapitala. Dio toga unutarnjeg tržišta čini i

\footnotetext{
* Dr. sc. Adriana Vincenca Padovan, izvanredna profesorica, Jadranski zavod Hrvatske akademije znanosti i umjetnosti; avpadovan@hazu.hr. ORCID: https://orcid.org/0000-0003-0013-1820.

** Mirela Duvnjak, dipl. prav., Croatia osiguranje d.d., Zagreb; duvnjak.mirela@gmail.com. ORCID: https://orcid.org/0000-0002-8315-0156.

1 Ugovor o funkcioniranju Europske unije (pročišćena verzija), SL C 202/1, 7.6.2016.
} 
tržište osiguranja. ${ }^{2}$

Člankom 49. UFEU-a zabranjuje se ,ograničivanje slobode poslovnog nastana državljana jedne države članice na državnom području druge države članice“, što uključuje i slobodu osnivanja zastupništava, podružnica ili društava kćeri. Nadalje, čl. 56. UFEU-a ,zabranjuju se ograničenja slobode pružanja usluga unutar Unije u odnosu na državljane država članica s poslovnim nastanom u državi članici koja nije država osobe kojoj su usluge namijenjene". Sloboda poslovnog nastana i sloboda kretanja usluga u sklopu unutarnjeg tržišta EU-a poglavito se uređuju odredbama čl. 49.-62. UFEU-a. ${ }^{3}$

Pravnim pravilima EU-a o slobodi pružanja usluga osiguranja i slobodi poslovnog nastana u sektoru osiguranja želi se omogućiti osobama koje su u potrazi za osigurateljnim proizvodima neograničen pristup pružateljima usluga osiguranja diljem EU-a i najširoj mogućoj ponudi osigurateljnih proizvoda dostupnih na jedinstvenom europskom tržištu, radi odabira onih proizvoda koji najbolje odgovaraju njihovim potrebama s obzirom na opseg osigurateljnog pokrića i cijenu osiguranja. ${ }^{4}$

Cilj je ovog rada analizirati važeći pravni okvir u Republici Hrvatskoj kojim se društvima za osiguranje jamče sloboda poslovnog nastana i sloboda prekograničnog pružanja usluga u skladu s pravnom stečevinom EU-a. Nadalje, u radu se analiziraju relevantni statistički podatci o poslovima osiguranja koje društva za osiguranje obavljaju na temelju slobode pružanja usluga i slobode poslovnog nastana u Republici Hrvatskoj i iz Republike Hrvatske u drugim članicama EU-a, kako bi se s pomoću konkretnih kvantitativnih pokazatelja prikazao stvaran učinak primjene relevantnoga pravnog okvira EU-a na industriju osiguranja u Republici Hrvatskoj.

Ovaj je rad prvi dio studije o prekograničnom obavljanju poslova osiguranja na jedinstvenom tržištu EU-a s aspekta hrvatskoga pravnog sustava. Autorice će u posebnom radu analizirati pojedine pravne aspekte koji bi mogli biti izazov za hrvatske osiguratelje i druge pružatelje usluga osiguranja ili izazvati dvojbe u tumačenju pravnih pravila o slobodi prekograničnog pružanja usluga osiguranja. U sklopu toga posebnog rada kao drugoga dijela predmetne studije autorice će dati određene preporuke koje bi domaćim osigurateljima i ostalim pružateljima usluga osiguranja mogle biti korisne kod donošenja poslovne odluke o mogućem prekograničnom obavljanju poslova osiguranja.

2 Ana Keglević, „Načela prava osiguranja u praksi Suda EU i njihov utjecaj na privatnopravne poretke država članica“, Zbornik Pravnog fakulteta u Zagrebu 62, br. 5-6 (2012): 1824.

3 Općenito o oslobodi pružanja usluga na unutarnjem tržištu EU-a vidi Hana Horak, Nada Bodiroga-Vukobrat, Kosjenka Dumančić, Sloboda pružanja usluga na unutarnjem tržištu Europske unije (Zagreb: Školska knjiga, 2015.). Vidi također Dionis Jurić, Jelena Jakšić, „Sloboda pružanja usluga u pravu Europske unije i njezino ostvarenje u Republici Hrvatskoj“, Hrvatska pravna revija 16, br. 10 (2016): 9-16. Detaljnije o uspostavi unutarnjeg tržišta osiguranja EU i tri slobode na kojima tržište djeluje vidi Loris Belanić, „Harmonizacija prava osiguranja u Europskoj uniji s osvrtom na ugovorno pravo osiguranja“, Zbornik Pravnog fakulteta u Zagrebu 60, br. 3 (2010): 1335-1368.

4 EU Commission, Commission interpretative communication-Freedom to provide services and the general good in the insurance sector, SL C 43, 16.2.2000., 5. 


\section{PRAVNI OKVIR ZA PREKOGRANIČNO POSLOVANJE DRUŠTAVA ZA OSIGURANJE}

\subsection{Pravni izvori}

Glavni izvor hrvatskoga nacionalnog prava koji uređuje slobodno pružanje usluga osiguranja i slobodu poslovnog nastana $u$ osigurateljnom sektoru na jedinstvenom unutarnjem tržištu EU-a je Zakon o osiguranju ${ }^{5}$ (dalje: ZOS). U dijelu prekograničnog obavljanja poslova obveznih osiguranja u prometu važan je i Zakon o obveznim osiguranjima u prometu ${ }^{6}$ (dalje: ZOOP).

Najvažniji izvori prava EU-a koji uređuju pitanja slobodnoga prekograničnog obavljanja poslova osiguranja su Direktiva 2009/138/EZ Europskog parlamenta i Vijeća od 25. studenoga 2009. o osnivanju i obavljanju djelatnosti osiguranja i reosiguranja (Solventnost II.) ${ }^{7}$ kako je izmijenjena i dopunjena te Direktiva (EU) 2016/97 Europskog parlamenta i Vijeća od 20. siječnja 2016. o distribuciji osiguranja. ${ }^{8,9}$ Obje direktive prenesene su u hrvatsko pravo ZOS-om.

Direktiva 2016/97 i Direktiva 2009/138 kao izvori sekundarnoga zakonodavstva Unije proizlaze iz načela i ciljeva utvrđenih ugovorima EU-a kao primarnim zakonodavstvom Unije te ih u skladu s njima treba i tumačiti, a ciljevi utvrđeni direktivama EU-a moraju se ostvariti u svim državama EU-a. ${ }^{10}$ Republika Hrvatska kao punopravna država članica EU-a ciljeve utvrđene navedenim direktivama o osiguranju ostvaruje putem ZOS-a i pripadajućih podzakonskih akata. Stoga se odredbe domaćih propisa o osiguranju kojima se u nacionalno zakonodavstvo prenose navedene direktive EU-a trebaju tumačiti u skladu s njihovim uniformnim tumačenjem i ciljevima i načelima utvrđenim primarnim zakonodavstvom Unije.

\subsection{Opće odredbe}

ZOS je temeljni pravni propis kojim se uređuje poslovanje društava za osiguranje, a među ostalim i uvjeti pod kojima društva za osiguranje i društva za reosiguranje iz drugih država članica mogu obavljati poslove osiguranja, ${ }^{11}$ odnosno poslove reosiguranja u Republici Hrvatskoj, kao i pod kojim uvjetima društva za osiguranje iz Republike Hrvatske mogu obavljati prekogranične poslove osiguranja u

5 Zakon o osiguranju, Narodne novine, br. 30/15., 112/18., 63/20., 133/20.

6 Zakon o obveznim osiguranjima u prometu, Narodne novine, br. 151/05., 36/09., 75/09., 76/13., $152 / 14$.

7 Direktiva 2009/138/EZ Europskog parlamenta i Vijeća od 25. studenoga 2009. o osnivanju i obavljanju djelatnosti osiguranja i reosiguranja (Solventnost II), SL L 335, 17.12.2009.

8 Direktiva (EU) 2016/97 Europskog parlamenta i Vijeća od 20. siječnja 2016. o distribuciji osiguranja, SL L 26, 2.2.2016.

9 Detaljnije o tri generacije direktiva EU-a o pravu osiguranja vidi Belanić, Harmonizacija prava osiguranja u Europskoj uniji s osvrtom na ugovorno pravo osiguranja, 1337-1349.

10 Za povijesni pregled razvoja načela prava osiguranja EU-a kroz tri generacije direktiva o osiguranju i prakse Suda EU-a vidi Keglević, Načela prava osiguranja u praksi Suda EU $i$ njihov utjecaj na privatnopravne poretke država članica.

11 Poslovi osiguranja su sklapanje i ispunjavanje ugovora o osiguranju (ZOS, čl. 7.). 
drugim državama članicama.

Osim društava za osiguranje i društava za uzajamno osiguranje sa sjedištem u Republici Hrvatskoj koje imaju odobrenje Hrvatske agencije za nadzor financijskih usluga (dalje: HANFA), poslove osiguranja u Republici Hrvatskoj temeljem čl. 17. st. 1. ZOS-a mogu obavljati i:

- društvo za osiguranje iz druge države članice koje, u skladu sa ZOS-om, ima pravo obavljati poslove osiguranja putem slobode pružanja usluga ili poslovnog nastana,

- društvo za osiguranje iz Švicarske Konfederacije koje ima odobrenje nadležnoga nadzornog tijela za obavljanje poslova osiguranja i koje u skladu sa ZOS-om ima pravo obavljati poslove osiguranja putem poslovnog nastana, kao i

- podružnica društva za osiguranje iz treće države koje ima odobrenje HANFA-e za obavljanje poslova osiguranja putem poslovnog nastana.

S time u vezi, osobitosti prekograničnog obavljanja poslova osiguranja uređene su u Glavi VI. ZOS-a, i to u tri poglavlja:

1. Obavljanje poslova osiguranja i poslova reosiguranja izvan područja Republike Hrvatske (čl. 61 - 65. ZOS-a),

2. Obavljanje poslova osiguranja društva za osiguranje iz druge države članice (čl. 66.-77. ZOS-a),

3. Obavljanje poslova osiguranja društava za osiguranje iz treće države (čl. 78.-85. ZOS-a).

Kako je predmet ovog rada prekogranično obavljanje poslova osiguranja unutar EU-a, usredotočit ćemo se na odredbe poglavlja 1. i 2. Glave VI. ZOS-a.

U skladu s čl. 13. st. 9. Direktive 2009/138, ZOS u čl. 3. st. 1. t. 17. propisuje kada se smatra da društvo za osiguranje obavlja poslove osiguranja po pravilima o slobodi pružanja usluga osiguranja, a kada na temelju slobode poslovnog nastana. Dakle, društvo za osiguranje registrirano u jednoj državi (matična država) obavlja poslove osiguranja na temelju slobode pružanja usluga kada se rizik (kod neživotnih osiguranja), odnosno obveza (kod životnih osiguranja) nalazi u drugoj državi članici (državi domaćinu), a to je onda ujedno država u kojoj se pružaju usluge. Društvo za osiguranje poslove osiguranja obavlja po načelu slobode poslovnog nastana kada preuzima rizike, odnosno obveze u drugoj državi članici poslujući putem podružnice osnovane u toj državi kao državi domaćinu.

Sukladno s čl. 3. st. 1. t. 18. ZOS-a, država članica u kojoj se nalazi rizik je:

a. država članica u kojoj se nalazi imovina, kad se osiguranje odnosi na zgrade ili na zgrade i njihov sadržaj, uz uvjet da je sadržaj pokriven istom policom osiguranja,

b. kada se osiguranje odnosi na bilo koju vrstu prijevoznog sredstva (vozilo, zrakoplov, brodicu, odnosno jahtu), država članica u kojoj je prijevozno sredstvo registrirano,

c. kada se osiguranje odnosi na bilo koju vrstu rizika povezanih s putovanjem ili godišnjim odmorom u slučaju polica koje traju četiri mjeseca ili kraće, država članica u kojoj je ugovaratelj sklopio ugovor o osiguranju, 
d. u svim slučajevima koji nisu izričito navedeni u točkama a), b) ili c), država članica u kojoj se nalazi:

- prebivalište ili uobičajeno boravište ugovaratelja osiguranja ako je ugovaratelj osiguranja fizička osoba ili

- poslovni nastan ugovaratelja osiguranja na koji se ugovor odnosi ako je ugovaratelj osiguranja pravna osoba.

Kod životnih osiguranja, po čl. 3. st. 1. t. 19. ZOS-a, država članica preuzimanja obveze je država članica u kojoj se nalazi:

- prebivalište ili uobičajeno boravište ugovaratelja osiguranja ili

- ako je ugovaratelj osiguranja pravna osoba, onaj poslovni nastan ugovaratelja osiguranja na koji se ugovor odnosi.

\subsection{Obavljanje poslova osiguranja i poslova reosiguranja u drugoj državi članici}

Prema čl. 61. ZOS-a, društvo za osiguranje, odnosno reosiguranje može poslove osiguranja, odnosno reosiguranja za koje ima odobrenje HANFA-e obavljati na području druge države članice na temelju:

- $\quad$ prava poslovnog nastana (ZOS, čl. 62.) ili

- $\quad$ slobode pružanja usluga (ZOS, čl. 63.). ${ }^{12}$

Poslovanju u drugoj državi članici na temelju prava poslovnog nastana prethodi obavještavanje HANFA-e o državi članici pružanja usluge, odnosno državi članici preuzimanja obveze na čijem teritoriju društvo za osiguranje namjerava osnovati podružnicu, uz obvezu dostavljanja odgovarajuće zakonom propisane dokumentacije i podataka (tzv. obveza notifikacije). Odluku u povodu pisane obavijesti HANFA je obvezna donijeti u roku od tri mjeseca od dana njena zaprimanja (čl. 62. st. 2. ZOS-a). Ako ne postoji sumnja u pravilnost poslovanja, o namjeri poslovanja putem podružnice HANFA će obavijestiti nadležno nadzorno tijelo države članice u kojoj društvo za osiguranje namjerava osnovati podružnicu.

Na temelju čl. 62. st. 6. ZOS-a društvo za osiguranje može osnovati podružnicu i početi obavljati poslove osiguranja u drugoj državi članici putem podružnice od dana kada je HANFA od nadležnoga nadzornog tijela države članice u kojoj se osniva podružnica zaprimila uvjete pod kojima sukladno s pravilima kojima se štiti opći interes, ${ }^{13}$ društvo za osiguranje može poslovati u toj državi članici. Ako HANFA-i nisu dostavljeni takvi uvjeti ili ako ih ne zaprimi, društvo za osiguranje može osnovati podružnicu i početi obavljati poslove osiguranja u drugoj državi članici putem podružnice protekom dva mjeseca od dana kada je nadležno nadzorno tijelo zaprimilo obavijest HANFA-e o namjeri osnivanja podružnice.

12 Na temelju čl. 438. ZOS-a postupanje protivno odredbama čl. 62.-64. ZOS-a kojima se uređuje prekogranično obavljanje poslova osiguranja u drugim državama članicama EU-a prekršaj je za koji se hrvatskom društvu za osiguranje, odnosno društvu za reosiguranje propisuje novčana kazna u visini od 75.000 do $150.000 \mathrm{kn}$, a za odgovornu osobu društva za osiguranje, odnosno reosiguranje u visini od 10.000 do $40.000 \mathrm{kn}$.

13 Detaljnije o pravilima kojima se štiti opći interes vidi infra § 2.6. Pravila kojima se štiti opći interes. 
Slične obveze društvo za osiguranje ima i kada namjerava poslove osiguranja obavljati u drugoj državi članici na temelju slobode pružanja usluga. Dakle, i u tom je slučaju društvo za osiguranje o takvoj namjeri dužno pisanim putem obavijestiti HANFA-u (tzv. obveza notifikacije) koja je svoju odluku obvezna donijeti u roku od mjesec dana od primitka te obavijesti (ZOS, čl. 63.). Ako nema sumnje u ispravnost takvoga poslovanja, zaprimljenu obavijest i pripadajuću dokumentaciju HANFA će dostaviti nadležnom nadzornom tijelu države članice u kojoj društvo za osiguranje namjerava obavljati poslove osiguranja na temelju slobode pružanja usluga, o čemu obavještava i društvo za osiguranje koje može početi obavljati poslove osiguranja nakon što je zaprimilo takvu obavijest.

Treba napomenuti da je društvo za osiguranje koje namjerava u drugoj državi članici pokrivati rizike iz osiguranja odgovornosti za uporabu motornih vozila (osim odgovornosti prijevoznika), bilo preko podružnice, bilo na temelju slobode pružanja usluga, obvezno predočiti izjavu da je postalo član nacionalnog ureda za osiguranje i nacionalnoga garancijskog fonda države članice domaćina ${ }^{14}$ i to prije početka neposrednog obavljanja te vrste poslova osiguranja (ZOS, čl. 62. st. 8 i čl. 63. st. 6. ).

Nadzor nad prekograničnim obavljanjem poslova osiguranja hrvatskih društava za osiguranje, kada je riječ o obavljanju poslova osiguranja na temelju prava poslovnog nastana ili slobode pružanja usluga, u pravilu provodi HANFA, ali se on može provesti i u suradnji s nadležnim nadzornim tijelom u državi članici domaćinu (ZOS, čl. 205. i 206.).

Posljednjim izmjenama i dopunama ZOS-a ${ }^{15}$ dodaju se članci 24.a i 24.b kojima je cilj jačanje suradnje i razmjena informacija između HANFA-e i nacionalnih nadzornih tijela drugih država članica EU-a, kao i između HANFA-e i Europskog nadzornog tijela za osiguranje i strukovno mirovinsko osiguranje (dalje: EIOPA), u obavljanju nadzora nad aktivnostima društava za osiguranje i reosiguranje temeljenih na slobodi pružanja usluga ili slobodi poslovnog nastana.

\subsection{Obavljanje poslova osiguranja društva za osiguranje iz druge države članice}

Kada društvo za osiguranje sa sjedištem u drugoj državi članici namjerava na temelju prava poslovnog nastana po prvi puta poslovati u Republici Hrvatskoj, ono je prethodno obvezno o tome obavijestiti nadležno nadzorno tijelo u matičnoj državi, kojemu tom prilikom dostavlja propisane podatke i dokumentaciju. ${ }^{16}$ Ako nema

14 Država članica domaćin je država članica EU-a koja nije matična država u kojoj društvo za osiguranje ili društvo za reosiguranje ima svoje sjedište, a u kojoj društvo za osiguranje, odnosno društvo za reosiguranje ima podružnicu ili u kojoj pruža usluge (ZOS, čl. 3. st. 1. t.16.).

15 Zakon o izmjenama i dopunama Zakona o osiguranju, Narodne novine, br. 133/20. Odredbe čl. 24.a i 24.b ZOS-a stupile su na snagu 30. lipnja 2021.

$16 \mathrm{Na}$ temelju čl. 439. ZOS-a postupanje protivno čl. 66.-73. ZOS-a kojima se uređuje prekogranično obavljanje poslova osiguranja u Republici Hrvatskoj iz drugih država članica EU-a prekršaj je za koji se društvu za osiguranje ili društvu za reosiguranje iz druge države članice, odnosno njihovoj podružnici u Republici Hrvatskoj propisuje novčana kazna u visini od 500.000 do $1.000 .000 \mathrm{kn}$, a za odgovornu osobu društva za osiguranje, odnosno reosiguranje 
sumnje u primjerenost sustava upravljanja, financijski položaj društva za osiguranje ili zahtjeve u vezi s primjerenošću te dobrim poslovnim ugledom i iskustvom ovlaštenog zastupnika, nadležno nadzorno tijelo matične države o namjeri društva za osiguranje da osnuje podružnicu u Republici Hrvatskoj obavještava HANFA-u (ZOS, čl. 66.). Bitno je napomenuti da je takvo društvo obvezno imenovati ovlaštenoga zastupnika te adresu u Republici Hrvatskoj na kojoj se mogu dobiti dokumenti i na koju se mogu dostaviti, uključujući sve obavijesti za ovlaštenoga zastupnika (ZOS, čl. 66. st. 2.).

Ako takvo društvo za osiguranje namjerava pružati usluge obveznih osiguranja u prometu uređenih ZOOP-om, obvezno je prije početka pružanja tih usluga HANFA-i dostaviti izjavu da je postalo članom nacionalnog ureda za osiguranje i nacionalnoga garancijskog fonda Republike Hrvatske (ZOS, čl. 66. st. 5. ZOS).

Društvo za osiguranje iz druge države članice može osnovati podružnicu na području Republike Hrvatske i početi poslovati od dana zaprimanja informacija vezanih za pravila kojima se štiti opći interes, ${ }^{17}$ ili ako ih ne zaprimi, nakon isteka dva mjeseca od dana kada je HANFA zaprimila obavijest i dokumentaciju nadležnoga nadzornog tijela o namjeri poslovanja putem prava poslovnog nastana (ZOS, čl. 66. st. 8.).

Kada društvo za osiguranje sa sjedištem u drugoj državi članici namjerava u Republici Hrvatskoj obavljati poslove osiguranja u skladu sa slobodom pružanja usluga, dužno je o tome prvo obavijestiti nadležno nadzorno tijelo svoje matične države članice, pritom navodeći prirodu rizika ili obveze koje namjerava pokrivati (ZOS, čl. 67.). Tako zaprimljenu obavijest i dokumentaciju zajedno s odgovarajućim potvrdama nadležno nadzorno tijelo dostavlja HANFA-i u roku od mjesec dana od zaprimanja obavijesti o namjeri poslovanja na području Republike Hrvatske. U slučaju namjere pružanja usluga obveznih osiguranja u prometu propisanih ZOOPom, društvo za osiguranje obvezno je HANFA-i dostaviti i ime i adresu predstavnika u vezi s pružanjem usluga obveznih osiguranja u prometu, kao i izjavu da je postalo članom Hrvatskog ureda za osiguranje i Garancijskog fonda u Republici Hrvatskoj (ZOS, čl. 67. st. 3.).

Neposredni nadzor nad financijskim poslovanjem podružnice društva za osiguranje iz druge države članice na području Republike Hrvatske obavlja nadležno nadzorno tijelo matične države članice samostalno ili putem imenovane osobe. Pritom HANFA može sudjelovati u takvom nadzoru (ZOS, čl. 207.).

Budući da je u stvarnosti odobrenje za prekogranično poslovanje društva za osiguranje države članice u nadležnosti nadzornog tijela matične države članice, postavlja se pitanje koje su mogućnosti HANFA-e kada utvrdi da takvo društvo za osiguranje koje posluje na teritoriju Republike Hrvatske po načelu poslovnog nastana ili na temelju slobode pružanja usluga nije usklađeno s propisima. Opcije koje su na raspolaganju HANFA-i u tom slučaju propisane su u čl. 73. ZOS-a. Mjere koje HANFA može primijeniti u tom slučaju uključuju izravni zahtjev prema tom društvu za osiguranje za otklanjanje nepravilnosti, obavještavanje nadležnoga nadzornog

u visini od 20.000 do $50.000 \mathrm{kn}$.

17 Detaljnije o pravilima kojima se štiti opći interes vidi infra § 2.6. Pravila kojima se štiti opći interes. 
tijela te upućivanje predmeta EIOPA-i sa zahtjevom za pomoć. Kao interventnu mjeru HANFA može poduzeti hitne mjere za sprječavanje ili kažnjavanje nepravilnosti na području Republike Hrvatske.

\subsubsection{Obrada odštetnih zahtjeva}

Pružanje usluga osiguranja izvan matične države ne smije rezultiratinepovoljnijim položajem podnositelja odštetnih zahtjeva po takvim ugovorima o osiguranju. ${ }^{18}$ Stoga čl. 69. ZOS-a izričito propisuje da je društvo za osiguranje sa sjedištem u drugoj državi članici obvezno osigurati da osobe koje su podnijele odštetne zahtjeve s osnova štetnih događaja koji su se ostvarili na području Republike Hrvatske nisu stavljene u nepovoljniji položaj zbog činjenice što to društvo pokriva rizike obveznih osiguranja u prometu putem slobode pružanja usluga u Republici Hrvatskoj, a ne preko poslovnog nastana (zabrana diskriminacije). Nadalje, čl. 70. ZOS-a propisuje obvezu društva za osiguranje da imenuje predstavnika s boravištem ili poslovnim nastanom na području Republike Hrvatske koji će prikupljati sve potrebne informacije u vezi s odštetnim zahtjevima i imati dostatne ovlasti da zastupa društvo za osiguranje u odnosu na osobe koje su pretrpjele štetu, uključujući isplate po tim zahtjevima te da zastupa ili prema potrebi osigura zastupanje društva za osiguranje pred HANFA-om, sudovima i tijelima Republike Hrvatske u vezi s tim zahtjevima.

\subsection{Porezi na premije kod prekograničnog osiguranja}

Neovisno o mjerodavnom pravu koje se primjenjuje na ugovor o osiguranju, po čl. 75. ZOS-a svaki ugovor o osiguranju isključivo podliježe neizravnim poreznim i parafiskalnim troškovima vezanim za premije osiguranja u državi članici u kojoj se nalazi rizik ili državi članici obveze. Način na koji će se osigurati naplata neizravnih poreza i parafiskalnih troškova od društava za osiguranje koja pokrivaju rizike ili obveze koji se nalaze na njihovu državnom području u nadležnosti je svake države članice.

Budući da države članice imaju različito uređen sustav oporezivanja premija osiguranja ovisno o rizicima, prilikom prekograničnog poslovanja vrlo je važno upoznati se s lokalnim pravilima vodeći računa o tome koji je porezni sustav mjerodavan, tj. porezni sustav države članice $u$ kojoj se nalazi rizik, odnosno države članice na čijem se državnom području nalazi osigurateljna obveza. Primjer takve publikacije objavljuje Insurance Europe pod naslovom Indirect taxation on insurance contracts in Europe. ${ }^{19} \mathrm{U}$ njoj se detaljno po državama daje pregled svih fiskalnih i parafiskalnih davanja ovisno o riziku te tipu poslovanja.

Kako bi osiguratelji mogli pravodobno ispunjavati obveze povezane $\mathrm{s}$ prekograničnim poslovanjem, a u vezi s time i uredno plaćati poreze i ostala davanja, preporuča se unaprjeđenje informatičke podrške koja će omogućiti da se takvi tipovi

18 Vidi čl. 150. i 151. Direktive 2009/138.

19 Insurance Europe: Indirect taxation on insurance contracts in Europe 2021, pristup 25. lipnja 2021., https://www.insuranceeurope.eu/publications/2287/indirect-taxation-on-insurancecontracts-in-europe-2021. 
ugovora o osiguranju odmah utvrde radi sprječavanja svih mogućih poslovnih rizika vezanih za prekogranično poslovanje (npr. ima li konkretan ugovor karakteristike prekograničnog osiguranja, je li obveza notifikacije provedena, je li članstvo u nacionalnom uredu, odnosno garancijskom fondu ishođeno, koliko iznose porezi i ostala davanja, kome se plaća, tko je ovlašteni predstavnik i sl.).

\subsection{Posebno o slobodi prekograničnog pružanja usluga osiguranja preko posrednika}

Društvo za osiguranje koje posluje po pravilima o slobodi pružanja usluga može osigurateljne proizvode u drugoj državi članici distribuirati izravno ili putem posrednika (npr. agencije, brokeri) ili putem sporednih posrednika (npr. zrakoplovne kompanije, rent-a-car kompanije, turističke agencije, prodavatelji elektroničkih uređaja itd.), pa treba imati na umu i pravila Direktive 2016/97 koja se odnose na slobodno pružanje usluga osiguranja od strane posrednika i sporednih posrednika u osiguranju, odnosno odgovarajuće odredbe ZOS-a kroz koje se navedena direktiva prenosi u hrvatsko nacionalno pravo.

Sukladno s čl. 404. st. 1. ZOS-a, društvo za osiguranje ne smije omogućiti da poslove distribucije osiguranja i distribucije reosiguranja obavljaju druge osobe osim ovlaštenih distributera osiguranja (iz čl. 401. ZOS-a), i to samo za distribuciju onih vrsta osiguranja za koje su upisani u registar HANFA-e ili notificirani za rad na području Republike Hrvatske. Kršenje ove obveze društva za osiguranje prekršaj je po ZOS-u za koji je predviđena novčana kazna od 150.000 do 750.000 kn za društvo za osiguranje (ZOS, čl. 444. st. 4. podstavak 3. t. 1.), odnosno u iznosu od 25.000 do 50.000 kn za odgovornu osobu u društvu za osiguranje (ZOS, čl. 444. st. 6.).

ZOS-om nije izričito predviđena sankcija ako se društvo za osiguranje koje posluje u drugoj državi članici po pravilima o slobodnom pružanju usluga osiguranja služi uslugama distributera osiguranja (npr. brokera ili zastupnika) koji nije notificiran za obavljanje poslova distribucije osiguranja u toj državi članici. Ipak, to bi bilo kršenje pravila o distribuciji osiguranja predviđenih Direktivom 2016/97 i stoga je za pretpostaviti da bi bilo kažnjivo u toj državi članici. ${ }^{20}$

20 Primjerice, ako se društvo za osiguranje iz druge države članice koje obavlja poslove distribucije osiguranja na temelju slobode pružanja usluga u Republici Hrvatskoj služi uslugama distribucije osiguranja od osobe koja nije upisana u registar HANFA-e ili notificirana za obavljanje poslova distribucije osiguranja u Republici Hrvatskoj, ono je u prekršaju po ZOS-u (arg. ZOS, čl. 444. st. 5. u vezi s čl. 444. st. 4. podstavak 3. točka 1). Slično tome bi društvo za osiguranje iz Hrvatske koje u drugoj državi članici obavlja poslove distribucije osiguranja na temelju slobode pružanja usluga u toj državi članici bilo u prekršaju u toj državi ako bi se služilo uslugama distribucije osiguranja od osobe koja nije registrirana ili notificirana za obavljanje distribucije osiguranja u toj državi članici. Ovo je stoga što su države članice prenoseći Direktivu 2016/97 u svoja nacionalna prava ovlaštene i dužne osigurati da njihova nadležna tijela uvedu odgovarajuće administrativne sankcije i druge mjere koje se primjenjuju na sva kršenja nacionalnih odredbi kojima se provodi ova direktiva te poduzimaju sve potrebne mjere kako bi se zajamčila njihova provedba. Države članice osiguravaju da su njihove administrativne sankcije i druge mjere djelotvorne, razmjerne i odvraćajuće (Direktiva 2016/97, čl. 31. st. 1.). Izričito je propisano da se sankcije trebaju primijeniti na društvo za osiguranje koje se koristi uslugama distribucije 
Dok s jedne strane ZOS propisuje (u skladu s čl. 13. st. 9. Direktive 2009/138) kada se smatra da društvo za osiguranje obavlja poslove osiguranja po pravilima o slobodi pružanja usluga osiguranja ${ }^{21} \mathrm{~s}$ druge nije predviđena izričita definicija slobode pružanja usluga u kontekstu distribucije osiguranja, ${ }^{22}$ tj. u smislu Direktive 2016/97, odnosno relevantnih odredbi glave XXIII. ZOS-a.

Sud EU-a tek treba u konkretnim slučajevima tumačiti temeljna načela slobode pružanja usluga u kontekstu distribucije osiguranja. Direktiva izričito ne definira ključni trenutak za početak primjene pravila o slobodi pružanja usluga, tj. kada i u kojoj državi članici se smatra da posrednik u osiguranju posluje na temelju slobode pružanja usluga. U nedostatku presedana Suda EU-a i pravne definicije, za sad je za razumijevanje koncepta slobode pružanja usluga u kontekstu distribucije osiguranja važno tumačenje EIOPA-e koje pojašnjava kada i gdje se smatra da posrednik obavlja prekograničnu distribuciju osiguranja po pravilima o slobodi pružanja usluga. ${ }^{23}$

Prema EIOPA-i, posrednik posluje na temelju slobode pružanja usluga:

- kada namjerava ugovaratelju osiguranja koji je rezident države članice različite od države članice registracije posrednika omogućiti sklapanje ugovora o osiguranju i

- kada se ugovor o osiguranju odnosi na rizik/obvezu koji se nalazi u državi članici različitoj od države registracije posrednika. ${ }^{24}$

Prema tumačenju EIOPA-e, posrednik ne posluje prekogranično na temelju slobode pružanja usluga:

osiguranja od osobe koja nije prijavila svoje poslove distribucije u skladu s čl. 3. Direktive (Direktiva 2016/97, čl. 33. st. 1. t. b). Među ostalim, u čl. 3. st. 1. podstavak 8. Direktive stoji da se u registar nadležnoga nadzornog tijela upisuju i države članice u kojima posrednik obavlja djelatnosti po pravilima o slobodi pružanja usluga odnosno po pravilima o slobodi poslovnog nastana (obveza notifikacije).

21 Vidi supra § 2.2. Opće odredbe.

22 Sukladno s čl. 399. st. 1. t. 1. „distribucija osiguranja“ djelatnost je predlaganja i sklapanja ugovora o osiguranju, savjetovanja o ugovorima o osiguranju ili obavljanja drugih pripremnih radnji za sklapanje ugovora o osiguranju, ili sklapanja takvih ugovora, ili pružanja pomoći pri upravljanju takvim ugovorima i njihovoj provedbi, posebice u slučaju rješavanja odštetnog zahtjeva, uključujući pružanje informacija o jednom ili više ugovora o osiguranju u skladu s kriterijima koje odabiru stranke putem mrežne stranice ili nekoga drugog medija i sastavljanje rang liste proizvoda osiguranja, uključujući i usporedbu cijena i proizvoda ili popust na cijenu ugovora o osiguranju, ako stranka može izravno ili neizravno sklopiti ugovor o osiguranju na mrežnoj stranici ili drugom mediju.

23 Steptoe \& Johnson LLP (Bruxelles), The Insurance Distribution Directive - A Handbook on Cross-Border Insurance Distribution by Insurance Intermediaries in the EU (Bruxelles: Bipar, January 2019), 10, pristup 28. lipnja 2021., https:/www.bipar.eu/en/page/bipar-handbookon-cross-border-insurance-distribution. Vidi također EIOPA: EIOPA Decision of the Board of Supervisors on the cooperation of the competent authorities of the Member States of the European Economic Area with regard to Directive (EU) 2016/97 of the European Parliament and of the Council of 20 January 2016 on insurance distribution, EIOPA BoS/18-340, 28 September 2018, § 2.2.1., str. 13-14, pristup 28. lipnja 2021., https://www.eiopa.europa.eu/ content/decision-cooperation-of-competent-authorities-under-idd.

24 Steptoe \& Johnson LLP (Bruxelles), The Insurance Distribution Directive - A Handbook on Cross-Border Insurance Distribution by Insurance Intermediaries in the EU. 
- ako je registriran u istoj državi članici u kojoj je ugovaratelj osiguranja rezident,

- ako je registriran u istoj državi članici u kojoj se nalazi rizik ili

- ako nema namjeru obavljati poslove prekogranične distribucije osiguranja. ${ }^{25}$

Radi lakšeg razumijevanja, u Tablici 1. daje se prikaz kombinacija.

Tablica 1. Kada posrednik u osiguranju prekogranično posluje na temelju slobode pružanja usluga? ${ }^{26}$

\begin{tabular}{|c|c|c|c|}
\hline Posrednik & Ugovaratelj osguranja & Rizik & FOS?* \\
\hline DČ 1 & DČ 1 & DČ 1 & $\mathrm{Ne}$ \\
\hline DČ 1 & DČ 1 & DČ 2 & $\mathrm{Ne}$ \\
\hline DČ 1 & DČ 2 & DČ 1 & $\mathrm{Ne}$ \\
\hline DČ 1 & DČ 2 & DČ 2 & $\mathrm{Da}$ \\
\hline DČ 1 & DČ 2 & DČ $2,3,4, \ldots$ & $\mathrm{Da}$ \\
\hline
\end{tabular}

* Uvjet je da posrednik svjesno namjerava poslovati prekogranično.

DČ = država članica

FOS $=$ prekogranično distribuiranje osiguranja na temelju slobode pružanja usluga

Za usporedbu, kod prekograničnog poslovanja društava za osiguranje sloboda pružanja usluga definirana je nešto drukčije, pa se radi lakšeg razumijevanja kombinacije prikazuju u Tablici 2.

Tablica 2. Kada društvo za osiguranje prekogranično posluje na temelju slobode pružanja usluga?

\begin{tabular}{|c|c|c|c|}
\hline Društvo za osiguranje & Ugovaratelj osguranja & Rizik & FOS?* \\
\hline DČ 1 & DČ 1 & DČ 1 & $\mathrm{Ne}$ \\
\hline DČ 1 & DČ 1 & DČ 2 & Da \\
\hline DČ 1 & DČ 2 & DČ 1 & $\mathrm{Ne}$ \\
\hline DČ 1 & DČ 2 & DČ 2 & Da \\
\hline DČ 1 & DČ 2 & DČ $2,3,4, \ldots$ & Da \\
\hline
\end{tabular}

Dakle, društvo za osiguranje može poslovati po pravilima o slobodnom pružanju usluga u državi članici (Direktiva 2009/138), a da lokalni posrednik u toj državi članici distribuira proizvode osiguranja toga društva za osiguranje izvan režima slobode prekograničnog pružanja usluga osiguranja (Direktiva 2016/97), jer je registriran u toj državi u kojoj se pružaju usluge i distribuira osiguranje ugovarateljima osiguranja

25 Steptoe \& Johnson LLP (Bruxelles), The Insurance Distribution Directive - A Handbook on Cross-Border Insurance Distribution by Insurance Intermediaries in the EU.

26 Tablica izrađena po uzoru na tablicu iz publikacije Steptoe \& Johnson LLP (Bruxelles), The Insurance Distribution Directive - A Handbook on Cross-Border Insurance Distribution by Insurance Intermediaries in the EU, 18. 
koji su također rezidenti u toj državi članici. ${ }^{27}$ Tako primjerice, posrednik registriran u državi članici 1 može omogućiti sklapanje ugovora o osiguranju trupa i stroja brodice registrirane u državi članici 2 ugovaratelju osiguranja koji je rezident u državi članici 1. Po interpretaciji EIOPA-e to ne bi bila prekogranična distribucija osiguranja. Međutim, ako je u opisanom slučaju osiguranje trupa i stroja brodice proizvod društva za osiguranje registriranog u državi članici 1 , onda to društvo za osiguranje $\mathrm{u}$ istom slučaju posluje u režimu slobode prekograničnog pružanja usluga osiguranja.

Društvo za osiguranje može poslove osiguranja za koje ima odobrenje HANFA-e obavljati na području druge države članice u skladu sa slobodom pružanja usluga ako ispunjava uvjete određene propisima države članice pružanja usluge, odnosno države članice preuzimanja obveze (ZOS, čl. 61.). Ni država članica u kojoj se rizik nalazi, a ni država članica obveze neće sprječavati ugovaratelja osiguranja da sklopi ugovor $\mathrm{s}$ društvom za osiguranje koje je dobilo odobrenje za rad, tj. obavljanje poslova osiguranja u određenim vrstama osiguranja od nadležnoga nadzornog tijela u svojoj matičnoj državi, sve dok sklapanje takvog ugovora nije suprotno propisima koji štite opći interes u državi članici u kojoj se nalazi rizik ili državi članici obveze (Direktiva 2009/138, čl. 180.).

Posrednik registriran u Republici Hrvatskoj mora notificirati svoju namjeru prekograničnog obavljanja poslova distribucije osiguranja HANFA-i. Pritom je obvezan prijaviti samo državu članicu u kojoj je ugovaratelj osiguranja (Odluka EIOPA-e, § 2.2.1.), bez obzira na državu u kojoj se nalazi rizik. ${ }^{28}$ Distributera osiguranja registriranog u Republici Hrvatskoj, tj. njegovu usklađenost s odredbama ZOS-a kojima se u hrvatsko pravo prenosi Direktiva 2016/97 nadzire HANFA, uključujući i njegove prekogranične poslove distribucije na temelju slobode pružanja usluga unutar EU-a. O njegovu mogućem kršenju pravila predviđenih Direktivom HANFA-u obavještava nadležno nadzorno tijelo države domaćina. Iznimno, nadležno nadzorno tijelo može poduzeti mjere protiv posrednika registriranog u Republici Hrvatskoj ako on nastavi ugrožavati prava potrošača unatoč mjerama i sankcijama koje primijeni HANFA, ili ako HANFA ne poduzme odgovarajuće mjere, odnosno u hitnim situacijama kada je to potrebno da se zaštite prava potrošača u državi domaćinu. Međutim, nadležno nadzorno tijelo države domaćina ovlašteno je sankcionirati sve distributere osiguranja koji posluju na njenom području za kršenje odredbi nacionalnog prava kojima se štiti opći interes u državi domaćinu (engl. general good rules). ${ }^{29}$

27 Steptoe \& Johnson LLP (Bruxelles), The Insurance Distribution Directive - A Handbook on Cross-Border Insurance Distribution by Insurance Intermediaries in the EU, 11.

28 Steptoe \& Johnson LLP (Bruxelles), The Insurance Distribution Directive - A Handbook on Cross-Border Insurance Distribution by Insurance Intermediaries in the EU, 13. Primjerice, uzmimo da hrvatski posrednik radi na ugovaranju osiguranja brodice registrirane na Malti za ugovaratelja osiguranja iz Španjolske. Posrednik bi u tom slučaju bio dužan notificirati se za slobodno pružanje usluga distribucije osiguranja na području Španjolske (domicil ugovaratelja osiguranja), ne i na području Malte (zemlja u kojoj se nalazi rizik prema čl. 3. st. 1. t. 18. ZOS-a).

29 Steptoe \& Johnson LLP (Bruxelles), The Insurance Distribution Directive - A Handbook on Cross-Border Insurance Distribution by Insurance Intermediaries in the EU, 16; vidi takoder čl. 5. Direktive 2016/97 i čl. 416.-421. ZOS-a. 


\subsection{Pravila kojima se štiti opći interes}

Pri prekograničnom poslovanju društva za osiguranje i posrednici u osiguranju moraju se pridržavati minimalnih standarda propisanih direktivama 2009/138 i 2016/97 te odredbi nacionalnoga prava države domaćina kojima se štiti opći interes. ${ }^{30}$ Nadležna nadzorna tijela država članica objavljuju nacionalne odredbe kojima se štiti opći interes na svojim mrežnim stranicama. ${ }^{31}$ Svaka država članica mora odrediti jedinstvenu točku kontakta za pribavljanje informacija o odredbama kojima se štiti

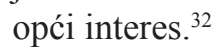

Pravila kojima se štiti opći interes norme su nacionalnoga prava države domaćina. Osnovno načelo u podlozi koncepta općeg interesa u osigurateljnom sektoru jest to da društva za osiguranje i posrednici u osiguranju koji osigurateljne proizvode distribuiraju prekogranično trebaju prilagoditi svoje poslovne aktivnosti pravilima koja vrijede u državi domaćinu, a kojima se štiti opći interes. ${ }^{33}$

U direktivama 2009/138 i 2016/97, kao ni u ostalim izvorima zakonodavstva EU-a, a ni u sudskoj praksi Suda EU-a ne nalazimo preciznu definiciju pravila kojima se štiti opći interes, već je riječ o pravnom konceptu koji se stalno razvija, osobito u praksi Suda EU-a. ${ }^{34}$ Europska komisija analizirala je praksu Suda EU-a po tom pitanju te je utvrdila određene uvjete koje prema stajalištu toga suda nacionalna norma mora ispuniti kako bi mogla opravdano i pravovaljano ograničiti slobodu poslovnog nastana i slobodu pružanja usluga, $\mathrm{tj}$. kako bi se mogla smatrati normom nacionalnoga

30 Radi preciznosti ovdje iznosimo jednu načelnu napomenu vezano za terminologiju. ZOS uvodi termin „opće dobro” u čl. 62., 74., 77., 418., 421., 425. prenoseći u domaće pravo odgovarajuće odredbe direktiva 2009/138 i 2016/97. Odgovarajući termin koji se koristi u engleskim verzijama ovih direktiva je ,general good”, u talijanskim verzijama ovih direktiva odgovarajući termin je „l'interesse generale”, u francuskim je ,intérêt general”. U hrvatskoj verziji Direktive 2009/138 nedosljedno se za isti pravni koncept koriste pojmovi „opće dobro” (u preambuli t. 77.-79. i 85. te čl. 146. i 156.) i ,javni interes” (u čl. 180). Hrvatska verzija Direktive 2016/87 koristi pojmove „opće dobro” " „opća dobra pravila”. Termin „opće dobro“pogrešno se koristi u ovom kontekstu te preporučamo koristiti primjereniji pojam ,javni interes“ ili „opći interes“. Riječ je o pravnim normama kojima se štiti opći interes. Pojam „opće dobro“ $u$ hrvatskom pravu ima sasvim drukčije značenje, tj. riječ je o stvarnopravnom pojmu. On označava dijelove prirode koji po svojim osobinama ne mogu biti u vlasti ni jedne fizičke ili pravne osobe pojedinačno, nego su na uporabi svih i izuzeti su od sposobnosti biti objektom stvarnih prava, kao što su to atmosferski zrak, voda u rijekama i jezerima, more i morska obala (čl. 3. Zakona o vlasništvu i drugim stvarnim pravima, Narodne novine, br. 91/96., 68/98., 137/99., 22/00., 73/00., 129/00., 114/01., 79/06., 141/06., 146/08., 38/09., 153/09., 143/12., 152/14.). Primjerice, Zakon o pomorskom dobru i morskim lukama (Narodne novine, br. 158/03., 100/04., 141/06., 38/09., 123/11., 56/16.) posebno uređuje pravni režim pomorskog dobra kao općeg dobra.

31 Poveznice na stranice nadležnih nadzornih tijela država članica objavljene su na mrežnim stranicama EIOPA-e: IDD General Good Provisions, pristup 28. lipnja 2021., https://www. eiopa.europa.eu/tools-and-data/idd-general-good-provisions_en.

32 Steptoe \& Johnson LLP (Bruxelles), The Insurance Distribution Directive - A Handbook on Cross-Border Insurance Distribution by Insurance Intermediaries in the EU, 14.

33 EIOPA: Insurance Distribution Directive - Report analysing national general Good, 2019, pristup 28. lipnja 2021., https:/www.eiopa.europa.eu/content/insurance-distribution-directivereport-analysing-national-general-good-rules_en.

34 EIOPA: Insurance Distribution Directive - Report analysing national general Good, 2019. 
prava osiguranja kojom se štiti opći interes. ${ }^{35}$ Zaključci ove analize objavljeni su u Interpretativnoj komunikaciji Komisije - Sloboda pružanja usluga i zaštita općeg interesa u osigurateljnom sektoru iz 2000. ${ }^{36}$

Prema tome, nacionalne norme kojima se štiti opći interes (engl. general good) kumulativno moraju ispunjavati nekoliko uvjeta kako bi bile u skladu s pravom EU-a:

- pravilo se mora odnositi na pitanja za koja nema usklađenih pravnih rješenja na razini EU-a,

- pravilo mora stvarno postizati cilj zaštite općeg interesa,

- pravilo se mora primjenjivati bez diskriminacije na sva društva za osiguranje, odnosno na sve distributere koji posluju u toj državi članici,

- pravilo mora biti objektivno nužno za postizanje cilja zaštite općeg interesa,

- pravilo mora biti proporcionalno cilju koji se njime postiže,

- u matičnoj državi članici nema odgovarajućih nacionalnih pravila koja štite isti cilj općeg interesa,

- države članice moraju osigurati da su administrativna opterećenja koja proizlaze iz nacionalnih pravila kojima se štiti opći interes proporcionalna cilju zaštite potrošača. ${ }^{37}$

Koncept nacionalnih pravila kojima se štiti opći interes u kontekstu direktiva 2009/138 i 2016/97, odnosno u Hrvatskoj u kontekstu ZOS-a, odnosi se ponajviše na kogentne pravne norme iz propisa o osiguranju. Primjerice HANFA je objavila odnosne odredbe hrvatskoga prava kojima se štiti opći interes, a primjenjuju se na sva društva za osiguranje i posrednike iz Europskoga gospodarskog prostora koje je, u skladu s čl. 147. Direktive 2009/138 ili čl. 4. Direktive 2016/97, ovlastilo nadležno tijelo matične države za obavljanje poslova osiguranja na području Republike Hrvatske. ${ }^{38}$ Riječ je o sažetku pravila kojima se štiti opći interes, a koja su inače obuhvaćena u ZOS-u i ZOOP-u.

Treba imati u vidu da, osim pravila kojima se štiti opći interes u državi domaćinu u kontekstu osigurateljnih propisa, društva za osiguranje i svi distributeri osiguranja koji posluju prekogranično po pravilima o slobodi poslovnog nastana, odnosno o slobodi pružanja usluga unutar EU-a moraju se pridržavati i drugih kogentnih propisa nacionalnoga prava države domaćina, uključujući, primjerice, porezne propise, kaznenopravne propise, propise o zaštiti potrošača, kogentne norme nacionalnog ugovornog prava (npr. zakonske norme o ništetnim ugovornim odredbama, kogentna pravila o osigurljivom interesu i sl.), kogentne norme međunarodnoga privatnog prava (npr. o izboru mjerodavnog prava za ugovor), propise o sprječavanju pranja novca, o

35 EIOPA: Insurance Distribution Directive - Report analysing national general Good, 2019.

36 EU Commission, Commission Interpretative Communication - Freedom to provide services and the general good in the insurance sector.

37 EU Commission, Commission Interpretative Communication - Freedom to provide services and the general good in the insurance sector, § II.2.b. Treba imati u vidu da ovaj popis uvjeta nije taksativan te da Sud EU-a pridržava pravo dodavati nove uvjete na njega u bilo kojem trenutku.

38 HANFA: Informacije o pravilima općeg dobra hrvatskog prava (obvezne odredbe hrvatskog prava), 2020., pristup 28. lipnja 2021., https://www.hanfa.hr/media/3593/pravilaop\%C4\%87eg-dobra.pdf. 
tržišnoj utakmici, o zaštiti osobnih podataka i sl.

\section{ANALIZA PREKOGRANIČNIH POSLOVA OSIGURANJA}

Na temelju čl. 202. st. 3. ZOS-a društvo za osiguranje obvezno je obavijestiti HANFA-u o statističkim podatcima o poslovima osiguranja, rizicima koje pokrivaju osiguranja, iznosu premija, štetama i provizijama, bez umanjenja za reosiguranje, po državama članicama, i to po vrstama neživotnih i životnih osiguranja, posebno za prekogranične poslove osiguranja koje obavlja na temelju slobode poslovnog nastana i posebno u skladu sa slobodom pružanja usluga.

\subsection{Društva za osiguranje na tř̌ištu Republike Hrvatske}

Prema podatcima dostupnim na mrežnim stranicama HANFA-e ${ }^{39}$ sa stanjem na dan 31. prosinca 2020. na tržištu Republike Hrvatske poslovalo je 15 osiguravajućih društava od čega je njih četiri poslovalo putem podružnica u državama članicama. Ukupnom broju osiguravajućih društava koja trenutačno posluju na području Republike Hrvatske treba dodati i tri podružnice društava za osiguranje iz država članica koja posluju na području Republike Hrvatske po načelu poslovnog nastana: 1. Porsche Versicherung Aktiengesellshaft Podružnica Zagreb za osiguranje, 2. Sava osiguranje d.d. Podružnica Zagreb za osiguranje i 3. Vereinigte Hegelversicherung VvaG Podružnica VH Hrvatska. ${ }^{40}$

Četiri domaća društva za osiguranje poslovala su izvan granica Republike Hrvatske u državama članicama po principu poslovnog nastana na dan 31. prosinca 2020. (podatci dostupni iz javnih registara), dok njih sedam u državama članicama posluje u skladu sa slobodom pružanja usluga (izvor: HANFA). Društva za osiguranje koja posluju u državama članicama putem podružnica su: Croatia osiguranje d.d. Zagreb (Slovenija), ${ }^{41}$ Allianz Hrvatska d.d. (Slovenija), ${ }^{42}$ Adriatic osiguranje d.d. (Italija) ${ }^{43}$ i Euroherc osiguranje d.d. (Austrija). ${ }^{44}$

S druge strane, od ukupnoga broja društava koja su obavijestila nadzorno tijelo

39 HANFA: Predložak A za objavu agregiranih statističkih podataka u vezi s društvima za osiguranje i društvima za reosiguranje nadziranima na temelju Direktive 2009/138/EZ, 2020., pristup 18. studenog 2021., https://www.hanfa.hr/trziste-osiguranja/regulativa/agregiranistatisticki-podaci/.

40 HANFA: Podružnice društava za osiguranje i/ili reosiguranje iz država članica EU, 2021., pristup 18. studenog 2021., https://www.hanfa.hr/trziste-osiguranja/registri/podruznicedrustava-za-osiguranje-iili-reosiguranje-iz-drzava-clanica-eu/.

41 AJPES - Agencija Republike Slovenije za javnopravne evidence in storitve, pristup 3. srpnja 2021., https://www.ajpes.si/prs/podjetjeSRG.asp?s=1\&e=641100.

42 AJPES - Agencija Republike Slovenije za javnopravne evidence in storitve, pristup 3. srpnja 2021., https://www.ajpes.si/prs/podjetjeSRG.asp?s=1\&e=696358.

43 IVASS - Istituto per la Vigilanza sulle Assicurazioni: Ettaglio Impresa D969R - ADRIATIC OSIGURANJE D.D., pristup 3. srpnja 2021., https://infostat-ivass.bancaditalia.it/RIGAInquirypublic/ng/\#/int-albi/search.

44 HF DATA - Firmenbuchauszug, Grundbuchauszug, GISA-Auszug online, pristup 3. srpnja 2021., https://www.firmenbuchgrundbuch.at/fbgb/easy/fb/documents?inputCommercialRegist erNumber $=468908 x \&$ affiliate $=-3 \&$ language $=$ de . 
o namjeri pružanja usluga osiguranja u Republici Hrvatskoj u skladu sa slobodom pružanja usluga, kojih je na dan 31. prosinca 2020. bilo ukupno 527, sa stanjem na dan 31. prosinca 2019. stvarno je tu uslugu pružalo njih $168 .{ }^{45}$ Od navedenoga broja prema dostupnim podatcima $s$ mrežnih stranica Hrvatskog ureda za osiguranje ${ }^{46}$ dva osiguravajuća društva članovi su nacionalnog ureda za osiguranje, odnosno Garancijskog fonda, i to Sava osiguranje d.d. Podružnica Hrvatska (Slovenija), te UK P\&I Club N.V. (Nizozemska). To znači da su se navedena društva notificirala za obavljanje poslova obveznih osiguranja u prometu za rizike preuzete na području Republike Hrvatske, tj. za pružanje usluga obveznih osiguranja u odnosu na prijevozna sredstva registrirana u Republici Hrvatskoj.

Tablica 3. Izvedeni podatci iz predloška A za objavu agregiranih statističkih podataka u vezi s društvima za osiguranje i društvima za reosiguranje nadziranima na temelju Direktive 2009/13847

\begin{tabular}{|l|c|c|c|c|c|}
\hline $\begin{array}{l}\text { NAČIN OBAVLJANJA } \\
\text { PRODAJE }\end{array}$ & \multicolumn{3}{|c|}{ BROJ DRUŠTVA ZA OSIGURANJE I REOSIGURANJE } \\
\cline { 2 - 6 } OSIGURANJA & 31.12 .2020$. & 31.12 .2019$. & 31.12 .2018 & 31.12 .2017$. & 31.12 .2016$. \\
\hline $\begin{array}{l}\text { Društva za osiguranje i } \\
\text { društva za reosiguranje } \\
\text { sa sjedištem u RH }\end{array}$ & 15 & 16 & 18 & 20 & 22 \\
\hline $\begin{array}{l}\text { Broj podružnica } \\
\text { društava za osiguranje } \\
\text { i reosiguranje iz država } \\
\text { članica EU s poslovnim } \\
\text { nastanom u RH }\end{array}$ & 3 & 4 & 4 & 4 & 4 \\
\hline $\begin{array}{l}\text { Broj podružnica } \\
\text { društava za osiguranje } \\
\text { i reosiguranje iz trećih } \\
\text { država s poslovnim } \\
\text { nastanom u RH }\end{array}$ & 0 & 0 & 0 & 0 & 0 \\
\hline $\begin{array}{l}\text { Broj podružnica u EU } \\
\text { društava za osigiranje } \\
\text { i reosiguranje sa } \\
\text { sjedištem u RH koja } \\
\text { obavljaju odgovarajuću } \\
\text { djelatnost u jednoj ili } \\
\text { više država članica }\end{array}$ & 4 & 4 & 3 & 2 & 2 \\
\hline
\end{tabular}

45 Podatak sa stanjem na 31.12.2020. u vrijeme pisanja ovog rada nije bio dostupan na mrežnim stranicama HANFA-e.

46 HUO: Članovi Hrvatskog ureda za osiguranje, pristup 3. srpnja 2021., https://huo.hr/hr/huo/ clanovi.

47 Izvor: HANFA (2021.). 


\begin{tabular}{|l|l|l|l|l|l|}
\hline $\begin{array}{l}\text { Broj država za } \\
\text { osiguranje sa sjedištem } \\
\text { u RH koja posluju } \\
\text { u drugim državama } \\
\text { članicama u skladu } \\
\text { sa slobodom pružanja } \\
\text { usluga }\end{array}$ & 7 & 6 & 5 & 5 & 4 \\
\hline $\begin{array}{l}\text { Broj država za } \\
\text { osiguranje sa sjedištem } \\
\text { u drugim državama } \\
\text { članicama EU koje su } \\
\text { obavijestile o svojoj } \\
\text { namjeri obavljanja } \\
\text { poslova osiguranja } \\
\text { u RH u skladu sa } \\
\text { slobodom pružanja } \\
\text { usluga }\end{array}$ & 527 & 515 & 482 & 464 & 418 \\
\hline $\begin{array}{l}\text { Broj država za } \\
\text { osiguranje s poslovnim } \\
\text { nastanom u drugim } \\
\text { državama članica EU } \\
\text { koje zaista obavljaju } \\
\text { djelatnost u RH u } \\
\text { skladu sa slobodom } \\
\text { pružanja usluga }\end{array}$ & - & 168 & 155 & 127 & 93 \\
\hline
\end{tabular}

\subsection{Zaračunata bruto premija u državama članicama}

Kao što je navedeno u prethodnom poglavlju, od ukupnog broja društava za osiguranje sa stanjem na dan 31. prosinca 2020. (15), njih četiri su poslovala u državama članicama u skladu s poslovnim nastanom, dok ih je sedam poslovalo $u$ skladu sa slobodom pružanja usluga. Ukupan iznos tako zarađene premije osiguranja raste po godinama uspoređujući podatke unazad četiri godine - od 68,02 milijuna kuna u 2017., 232,19 milijuna kuna u 2018., 434,66 milijuna kuna u 2019., do 648,86 milijuna kuna u 2020. ${ }^{48}$ Kada se navedeni iznos stavi u omjer ukupne zaračunate premije svih društava za osiguranje za 2020. koji je iznosio 10.481,57 milijuna kuna, tada možemo vidjeti da iznos tako zaračunate premije za sada predstavlja $6,2 \%$ od toga ukupnog iznosa premije. Ako se taj udio promatra po vrstama osiguranja, tada omjer zaračunate bruto premije neživotnih osiguranja iz prekograničnih osiguranja u ukupno zaračunatoj bruto premiji osiguranja svih društava za osiguranje iz RH tijekom 2020. godine čini 8,3\%, a životnih osiguranja $0,01 \%$.

48 HANFA: Društva za osiguranje i reosiguranje; Statistika osiguranja za 2017., 2018, 2019. i 2020. godinu, pristup 18. studeni 2021., na https://www.hanfa.hr/publikacije/statistika/\#section1. 
Tablica 4. Broj osiguranja i zaračunata bruto premija po osnovi prekograničnog osiguranja društava za osiguranje sa sjedištem u Republici Hrvatskoj ${ }^{49}$

\begin{tabular}{|c|c|c|c|c|c|c|c|c|c|}
\hline \multirow{2}{*}{ Šfía } & \multirow{2}{*}{ VRSTE OSIGURANJA } & \multicolumn{2}{|c|}{$\begin{array}{l}\text { PREKOGRANIČNA OSIGURANJA } \\
\text { (2020) }\end{array}$} & \multicolumn{2}{|c|}{$\begin{array}{l}\text { PREKOGRANČ̌NA OSIGURANJA } \\
\text { (2019) }\end{array}$} & \multicolumn{2}{|c|}{$\begin{array}{l}\text { PREKOGRANIČNA OSIGURANJA } \\
\text { (2018) }\end{array}$} & \multicolumn{2}{|c|}{$\begin{array}{l}\text { PREKOGRANIČNA OSIGURANJA } \\
\text { (2017) }\end{array}$} \\
\hline & & $\begin{array}{c}\text { Broj } \\
\text { osiguranja }\end{array}$ & $\begin{array}{l}\text { Zaračunata } \\
\text { bruto premija* }\end{array}$ & $\begin{array}{c}\text { Broj } \\
\text { osiguranja }\end{array}$ & $\begin{array}{c}\text { Zaračunata } \\
\text { bruto premija* }\end{array}$ & $\begin{array}{c}\text { Broj } \\
\text { osiguranja }\end{array}$ & $\begin{array}{l}\text { Zaračunata } \\
\text { bruto premija* }\end{array}$ & \begin{tabular}{|c|} 
Broj \\
osiguranja
\end{tabular} & $\begin{array}{l}\text { Zaračunata } \\
\text { bruto premija* }\end{array}$ \\
\hline 01 & OSIGURANJE OD NEZGODE & 60.828 & 12.165 .317 & 33.098 & 7.305 .668 & 5.265 & 1.525 .351 & 1.268 & 339.314 \\
\hline 02 & ZDRAVSTVENO OSIGURANJE & & & & & & & & \\
\hline 03 & $\begin{array}{l}\text { OSIGURANJE CESTOVNIH } \\
\text { VOZILA }\end{array}$ & 44.183 & 109.104 .533 & 29.096 & 91.885 .846 & 10.823 & 53.066 .438 & 1.854 & 11.043 .810 \\
\hline 04 & OSIGURANJE TRAČNIH VOZILA & & & & & & & & \\
\hline 05 & $\begin{array}{l}\text { OSIGURANJE ZRAČNIH } \\
\text { LETJELICA }\end{array}$ & 15 & 357.538 & 14 & 172.211 & 7 & 193.449 & & \\
\hline 06 & OSIGURANJE PLOVILA & 989 & 9.145 .097 & 1.111 & 8.522 .876 & 462 & 3.598 .031 & 557 & 4.944.137 \\
\hline 07 & $\begin{array}{l}\text { OSIGURANJE ROBE U } \\
\text { PRIJEVOZU }\end{array}$ & 23 & 347.164 & 9 & 242.989 & 4 & 77.781 & 1 & 839 \\
\hline 08 & $\begin{array}{l}\text { OSIGURANJE OD POŽARA I } \\
\text { ELEMENTARNIH ŠTETA }\end{array}$ & 4.873 & 21.616 .310 & 1.883 & 19.512 .133 & 432 & 9.894 .586 & 48 & 1.925 .310 \\
\hline 09 & OSTALA OSIGURANJA IMOVINE & 8.321 & 37.570 .851 & 4.276 & 43.799 .218 & 1.764 & 11.383 .040 & 354 & 1.288 .395 \\
\hline 10 & $\begin{array}{l}\text { OSIGURANJE OD } \\
\text { ODGOVORNOSTI ZA UPOTREBU } \\
\text { MOTORNIH VOZILA }\end{array}$ & 216.149 & 403.613 .668 & 128.482 & 197.757.311 & 66.638 & 129.929 .332 & 17.984 & 37.865 .155 \\
\hline 11 & $\begin{array}{l}\text { OSIGURANJE OD } \\
\text { ODGOVORNOSTI ZA UPOTREBU } \\
\text { ZRAČNIH LETJELICA }\end{array}$ & 37 & 326.532 & 40 & 209.282 & 34 & 167.089 & 1 & 1.959 \\
\hline 12 & $\begin{array}{l}\text { OSIGURANJE OD } \\
\text { ODGOVORNOSTI ZA UPOTREBU } \\
\text { PLOVILA }\end{array}$ & 1.550 & 1.341 .426 & 1.962 & 1.583 .751 & 585 & 637.947 & 859 & 808.672 \\
\hline 13 & $\begin{array}{l}\text { OSTALA OSIGURANJA OD } \\
\text { ODGOVORNOSTI }\end{array}$ & 4.512 & 28.571 .038 & 1.909 & 34.449 .422 & 481 & 10.840 .278 & 25 & 996.986 \\
\hline 14 & OSIGURANJE KREDITA & 3.198 & 6.470 .675 & 9.498 & 20.046 .961 & 3.187 & 6.160 .491 & & \\
\hline 15 & OSIGURANJE JAMSTAVA & & & & & & & & \\
\hline 16 & $\begin{array}{l}\text { OSIGURANJE RAZNIH } \\
\text { FINANCIJSKIH GUBITAKA }\end{array}$ & 691 & 2.263 .622 & 1.548 & 2.653 .825 & 2.925 & 1.934 .373 & 786 & 403.101 \\
\hline 17 & $\begin{array}{l}\text { OSIGURANJE TROŠKOVA } \\
\text { PRAVNE ZAŠTITE }\end{array}$ & 3.369 & 998.119 & 3.717 & 1.116 .967 & 2.381 & 778.852 & & \\
\hline 18 & $\begin{array}{l}\text { OSIGURANJE POMOĆI } \\
\text { (ASISTENCIJA) }\end{array}$ & 73.953 & 14.619 .281 & 25.337 & 4.996 .600 & 8.270 & 1.198 .329 & 1.804 & 251.170 \\
\hline 19 & ŽNOTNO OSIGURANJE & 310 & 274.551 & 256 & 382.474 & 131 & 743.304 & 101 & 196.553 \\
\hline 20 & RENTNO OSIGURANJE & & & & & & & & \\
\hline 21 & $\begin{array}{l}\text { DOPUNSKA OSIGURANJA UZ } \\
\text { OSIGURANJE ŽIVOTA }\end{array}$ & 202 & 46.218 & 178 & 31.893 & 106 & 5.404 & 88 & 29.588 \\
\hline 22 & $\begin{array}{l}\text { OSIGURANJE ZA SLUČAJ } \\
\text { VJENČANJA }\end{array}$ & & & & & & & & \\
\hline 23 & $\begin{array}{l}\text { ŽVOTNA III RENTNA } \\
\text { OSIGURANJA KOD KOJH } \\
\text { UGOVARATELJ SNOSI RIZIK }\end{array}$ & 67 & 29.868 & 52 & & 52 & 58.457 & 51 & 7.934 .656 \\
\hline 24 & TONIINE & & & & & & & & \\
\hline 25 & $\begin{array}{l}\text { OSIGURANJE S } \\
\text { KAPITALIZACIJOM ISPLATE }\end{array}$ & & & & & & & & \\
\hline & $\begin{array}{l}\text { UKUPNO NEŽIVOTNA } \\
\text { OSIGURANJA }\end{array}$ & 422.691 & 648.511 .171 & 241.980 & 434.255 .061 & 103.258 & 231.385 .367 & 25.541 & 59.868 .848 \\
\hline & $\begin{array}{l}\text { UKUPNO ŽIVOTNA } \\
\text { OSIGURANJA }\end{array}$ & 579 & 350.637 & 486 & 414.366 & 289 & 807.165 & 240 & 8.160 .797 \\
\hline & $\begin{array}{l}\text { SVEUKUPNO } \\
\text { (viste } 01 \text { - 25) }\end{array}$ & 423.270 & 648.861 .808 & 242.466 & 434.669.427 & 103.547 & 232.192.532 & 25.781 & 68.029 .645 \\
\hline
\end{tabular}

Od ukupnog iznosa premije osiguranja koja je s osnove prekograničnih osiguranja zaračunata tijekom 2020. godine i koja je iznosila 648,86 milijuna kuna, $94 \%$, odnosno 612,6 milijuna kuna odnosi se na poslovanje na temelju slobode poslovnog nastana, dok se $6 \%$ toga iznosa, odnosno 36,2 milijuna kuna odnosi na poslovanje u skladu sa slobodom pružanja usluga. Ako promatramo po skupinama osiguranja tada se može zamijetiti da se $99,95 \%$ tako zarađene premije osiguranja odnosi na neživotna osiguranja dok se $0,05 \%$ odnosi na vrste osiguranja iz skupine životnih osiguranja. U pogledu neživotnih osiguranja glavnina premijskog prihoda dolazi od obveznih osiguranja od odgovornosti za upotrebu motornih vozila $(62,2 \%)$, zatim slijede kasko osiguranje cestovnih vozila (16,8\%) te ostala osiguranja imovine

49 Izvor: HANFA (2021.). 
$(5,8 \%)$. Promatrajući po državama članicama $40 \%$ iznosa premije osiguranja (tj. 259,73 milijuna kuna) zaračunato je po rizicima, odnosno obvezama preuzetim u Austriji, nakon čega slijedi Italija s $33 \%$ udjela (213,87 milijuna kn) te Slovenija s $26 \%$ udjela (168,32 milijuna kuna). Znatnije povećanje premijskoga prihoda koje je utvrđeno u 2020. u odnosu na 2019. ponajviše proizlazi iz povećanja premije osiguranja ostvarene iz poslovanja na temelju slobode poslovnog nastana $\mathrm{u}$ Italiji $\mathrm{i}$ to za $+190,18$ milijuna kuna (u 2019. premija je iznosila 11,07 milijuna kuna, dok je u 2020. zaračunata premija u visini od 201,26 milijuna kuna).

Najveći iznos premije osiguranja zarađene po načelu slobode pružanja usluga odnosi se na grupu osiguranja iz skupine 10. Osiguranje od odgovornosti za upotrebu motornih vozila (32\%), dok se $25 \%$ tako zarađene premije odnosi na skupinu 6 . Osiguranje plovila, odnosno $18 \%$ u skupini 14. Osiguranje kredita.

Nažalost, na mrežnim stranicama HANFA-e nisu dostupni podatci o zaračunatom iznosu premije osiguranja koja društva za osiguranje iz država članica prihoduju iz obveza, odnosno rizika preuzetih na području Republike Hrvatske ${ }^{50}$ na temelju slobode poslovnog nastana, odnosno slobode pružanja usluga.

\section{ZAKLJUČAK}

Sloboda pružanja usluga i sloboda poslovnog nastana jedne su od temeljnih gospodarskih sloboda na tržištu Europske unije. Postavši članicom Unije u srpnju 2013. Republika Hrvatska postala je ravnopravan član toga gospodarskog prostora te je dobila priliku ostvariti koristi koje proizlaze iz toga članstva.

Kao i kod drugih gospodarskih grana, ova sloboda nije neograničena niu kontekstu djelatnosti osiguranja. Pravni okvir postavljen direktivama 2009/138 i 2016/97 u zakonodavstvo Republike Hrvatske prenesen je ZOS-om. ZOS društvima za osiguranje i ostalim pružateljima usluga osiguranja iz država članica jamči slobodno obavljanje poslova osiguranja na području Republike Hrvatske na temelju slobode poslovnog nastana i slobode pružanja usluga, pritom poštujući hrvatska nacionalna pravila kojima se štiti opći interes u sektoru osiguranja. Istodobno, društvima za osiguranje i ostalim pružateljima usluga osiguranja iz Republike Hrvatske zajamčena je sloboda prekograničnog pružanja osiguranja i sloboda poslovnog nastana na jedinstvenom unutarnjem tržištu EU-a. Budući da poslovanje po osnovi prekograničnog osiguranja osim premijskog prihoda nosi sa sobom i veliki broj obveza, počevši od pravodobne notifikacije, plaćanja poreza i ostalih davanja, imenovanje ovlaštenog predstavnika do članstva u nacionalnim uredima i garancijskim fondovima kod određenih vrsta osiguranja, društva za osiguranje moraju se precizno i na vrijeme pripremiti za takve vrste poslova i procijeniti njihovu isplativost kako bi izbjegli moguće sankcije i druge poslovne rizike.

Premije osiguranja koje domaća društva za osiguranje zaračunavaju s osnove

50 Podatci su zatraženi pisanim putem, međutim, HANFA drži podatke poslovnom tajnom i ne dostavlja ih na uvid trećim osobama. Po pisanoj uputi HANFA-e podatci su zatraženi i od EIOPA-e koji u svom odgovoru pojašnjava da takve podatke smatra povjerljivima, pa ih ne čini dostupnima trećim osobama. 
prekograničnog osiguranja trenutačno iznose nešto više od $6 \%$ od ukupnog iznosa premija osiguranja, ali taj se udio povećava proteklih godina, a glavnina se odnosi na poslovanje s osnova slobode poslovnog nastana. Najveći hrvatski osiguratelji hrabro su krenuli u tržišnu utakmicu u susjednim europskim zemljama (Austrija, Italija, Slovenija) i bit će zanimljivo promatrati kako će se uspjeti nositi s konkurentima iz tih zemalja.

U budućim istraživanjima bilo bi zanimljivo usporediti premije osiguranja koje društva za osiguranje iz drugih država članica prihoduju za rizike i obveze preuzete na području Republike Hrvatske kada ti podatci budu dostupni. Nadamo se ipak da će HANFA i te podatke prikazati u nekim od svojih budućih publikacija.

\section{LITERATURA}

1. Betetto, Nina. U: Pravdni postopek: Zakon s komentarjem, 2. knjiga, ur. Lojze Ude et al. Ljubljana: Uradni list Republike Slovenije: GV založba, 2006.

2. Bydlinski, Michael. U: Kommentar zu den Zivilprozessgesetzen 2. Band / 1. Teilband EGZPO, $\S \S 1$ bis 73 ZPO, Hans Walter Fasching, Andreas Konecny. Wien: Manz, 2002.

3. Dika, Mihajlo. Građansko parnično pravo. Knj. 4: Stranke, njihovi zastupnici i treći u parničnom postupku. Zagreb: Narodne novine, 2008.

4. AJPES - Agencija Republike Slovenije za javnopravne evidence in storitve. Pristup 3. srpnja 2021., https://www.ajpes.si/prs/podjetjeSRG.asp?s=1\&e=641100

5. AJPES - Agencija Republike Slovenije za javnopravne evidence in storitve. Pristup 3. srpnja 2021., https://www.ajpes.si/prs/podjetjeSRG.asp?s=1\&e=696358

6. Belanić, Loris. „Harmonizacija prava osiguranja u Europskoj uniji s osvrtom na ugovorno pravo osiguranja“. Zbornik Pravnog fakulteta u Zagrebu 60, br. 3 (2010): 1335-1368.

7. Direktiva (EU) 2016/97 Europskog parlamenta i Vijeća od 20. siječnja 2016. o distribuciji osiguranja, SL L 26, 2.2.2016.

8. Direktiva 2009/138/EZ Europskog parlamenta i Vijeća od 25. studenoga 2009. o osnivanju i obavljanju djelatnosti osiguranja i reosiguranja (Solventnost II), SL L 335, 17.12.2009.

9. EIOPA: EIOPA Decision of the Board of Supervisors on the cooperation of the competent authorities of the Member States of the European Economic Area with regard to Directive (EU) 2016/97 of the European Parliament and of the Council of 20 January 2016 on insurance distribution, EIOPA BoS/18-340, 28 September 2018. Pristup 28. lipnja 2021., https://www.eiopa.europa.eu/content/decision-cooperation-of-competent-authoritiesunder-idd.

10. EIOPA: IDD General Good Provisions. Pristup 28. lipnja 2021., https://www.eiopa. europa.eu/tools-and-data/idd-general-good-provisions_en

11. EIOPA: Insurance Distribution Directive - Report analysing national general Good, 2019. Pristup 28. lipnja 2021., https://www.eiopa.europa.eu/content/insurance-distributiondirective-report-analysing-national-general-good-rules_en

12. EU Commission: Commission interpretative communication - Freedom to provide services and the general good in the insurance sector, OJ C 43, 16.2.2000., 5-27.

13. HANFA: Društva za osiguranje i reosiguranje; Statistika osiguranja za 2017., 2018., 2019 i 2020. godinu. Pristup 18. studeni 2021., https://www.hanfa.hr/publikacije/ statistika/\#section1

14. HANFA: Informacije o pravilima općeg dobra hrvatskog prava (obvezne odredbe hrvatskog prava), 2020. Pristup 28. lipnja 2021., https://www.hanfa.hr/media/3593/ pravila-op $\% \mathrm{C} 4 \% 87$ eg-dobra.pdf 
15. HANFA: Podružnice društava za osiguranje i/ili reosiguranje iz država članica EU, 2020. Pristup 18. studeni 2021., https://www.hanfa.hr/trziste-osiguranja/registri/podruznicedrustava-za-osiguranje-iili-reosiguranje-iz-drzava-clanica-eu/

16. HANFA: Predložak A za objavu agregiranih statističkih podataka u vezi s društvima za osiguranje i društvima za reosiguranje nadziranima na temelju Direktive 2009/138/ EZ, 2020. Pristup 18. studeni 2021., https://www.hanfa.hr/trziste-osiguranja/regulativa/ agregirani-statisticki-podaci/

17. HF DATA - Firmenbuchauszug, Grundbuchauszug, GISA-Auszug online. Pristup 3. srpnja 2021., https://www.firmenbuchgrundbuch.at/fbgb/easy/fb/documents?inputCommercial RegisterNumber $=468908 x$ \&affiliate $=-3$ \&language $=$ de

18. Horak, Hana, Nada Bodiroga-Vukobrat i Kosjenka Dumančić. Sloboda pružanja usluga na unutarnjem tržištu Europske unije. Zagreb: Školska knjiga, 2015.

19. HUO: Članovi Hrvatskog ureda za osiguranje. Pristup 3. srpnja 2021., https://huo.hr/hr/ huo/clanovi

20. Insurance Europe: Indirect taxation on insurance contracts in Europe 2021. Pristup 25. lipnja 2021., https://www.insuranceeurope.eu/publications/2287/indirect-taxation-oninsurance-contracts-in-europe-2021

21. IVASS - Istituto per la Vigilanza sulle Assicurazioni: Ettaglio Impresa D969R - ADRIATIC OSIGURANJE D.D. Pristup 3. srpnja 2021., https://infostat-ivass.bancaditalia.it/ RIGAInquiry-public/ng/\#/int-albi/search

22. Jurić, Dionis i Jelena Jakšić. „Sloboda pružanja usluga u pravu Europske unije i njezino ostvarenje u Republici Hrvatskoj“. Hrvatska pravna revija 16, br. 10 (2016): 9-16.

23. Keglević, Ana. „Načela prava osiguranja u praksi Suda EU i njihov utjecaj na privatnopravne poretke država članica“. Zbornik Pravnog fakulteta u Zagrebu 62, br. 5-6 (2012): 1823-1858.

24. Steptoe \& Johnson LLP (Bruxelles). The Insurance Distribution Directive - A Handbook on Cross-Border Insurance Distribution by Insurance Intermediaries in the EU, Bruxelles: Bipar, January 2019. Pristup 28. lipnja 2021., https://www.bipar.eu/en/page/ bipar-handbook-on-cross-border-insurance-distribution.

25. Ugovor o funkcioniranju Europske unije (pročišćena verzija), SL C 202/1, 7.6.2016.

26. Zakon o izmjenama i dopunama Zakona o osiguranju, Narodne novine, br. 133/20.

27. Zakon o obveznim osiguranjima u prometu, Narodne novine, br. 151/05., 36/09., 75/09., 76/13., 152/14.

28. Zakon o osiguranju, Narodne novine, br. 30/15., 112/18., 63/20., 133/20.

29. Zakon o pomorskom dobru i morskim lukama, Narodne novine, br. 158/03., 100/04., 141/06., 38/09., 123/11., 56/16.

30. Zakon o vlasništvu i drugim stvarnim pravima, Narodne novine, br. 91/96., 68/98., 137/99., 22/00., 73/00., 129/00., 114/01., 79/06., 141/06., 146/08., 38/09., 153/09., $143 / 12 ., 152 / 14$. 


\section{Adriana Vincenca Padovan* \\ Mirela Duvnjak**}

Summary

\section{CROSS-BORDER INSURANCE BUSINESS ON THE EUROPEAN UNION SINGLE MARKET - A CROATIAN PERSPECTIVE}

The authors analyse the legal framework for carrying on cross-border insurance business within the EU with special reference to the current legal system in the Republic of Croatia. Furthermore, the authors present the relevant statistical data on insurance business carried on under the rules on establishment or on the freedom to provide insurance services in and from the Republic of Croatia. The aim is to demonstrate how the implementation of the EU legislation on the freedom of establishment and freedom to provide insurance services affects the local insurance industry and to point at the challenges that the liberalisation of insurance services places in front of the insurance companies and other insurance service providers in the Republic of Croatia.

Keywords: freedom to provide services; freedom of establishment; European union; insurance; reinsurance; Directive 2009/138/EZ; Directive (EU) 2016/97; Croatian Insurance Act.

* Dr. sc. Adriana Vincenca Padovan, Associate Professor, Adriatic Institute, Croatian Academy of Sciences and Arts; avpadovan@hazu.hr. ORCID: https://orcid.org/0000-0003-0013-1820.

** Dr. Mirela Duvnjak, dipl. iur, Croatia osiguranje d.d., Zagreb; duvnjak.mirela@gmail.com. ORCID: https://orcid.org/0000-0000-0002-8315-0156. 